\title{
Phylogenetic relationship of Japanese Podismini species (Orthoptera: Acrididae: Melanoplinae) inferred from a partial sequence of cytochrome c oxidase subunit I gene
}

\author{
Beata Grzywacz ${ }^{1,2}$, Haruki Tatsuta'
}

1 Department of Ecology and Environmental Sciences, Faculty of Agriculture, University of the Ryukyus, Nishihara, Okinawa, Japan. 2 Institute of Systematics and Evolution of Animals, Polish Academy of Sciences, Sławkowska 17, 31-016 Krakow, Poland.

Corresponding author: B. Grzywacz (grzywacz@isez.pan.krakow.pl)

Academic editor: Corinna Bazelet | Received 19 July 2016 | Accepted 4 July 2017 | Published 28 June 2017

http://zoobank.org/B89916BC-A54B-4B92-97DE-9D1BF03BE8A6

Citation: Grzywacz B, Tatsuta H (2017) Phylogenetic relationship of Japanese Podismini species (Orthoptera: Acrididae: Melanoplinae) inferred from a partial sequence of cytochrome c oxidase subunit I gene. Journal of Orthoptera Research 26(1): 11-19. https://doi.org/10.3897/jor.26.14547

\begin{abstract}
Members of the tribe Podismini (Orthoptera: Acrididae: Melanoplinae) are distributed mainly in Eurasia and the western and eastern regions of North America. The primary aim of this study is to explore the phylogenetic relationship of Japanese Podismini grasshoppers by comparing partial sequences of cytochrome c oxidase subunit I (COI) mitochondrial gene. Forty podismine species (including nineteen Japanese species) and thirty-seven species from other tribes of the Melanoplinae (Dactylotini, Dichroplini, Melanoplini, and Jivarini) were used in the analyses. All the Japanese Podismini, except Anapodisma, were placed in a well-supported subclade. However, our results did not correspond with the classification on the basis of morphological similarity for the status of Tonkinacridina. This group of Japanese species constituted a single clade with other species of Miramellina and Podismina, while Eurasian continental species of Tonkinacridina were placed in other separate clades. This incongruence might have resulted from historical migratory events between continent and ancient islands and subsequent convergent/parallel evolution in morphology. Some remarks on phylogenetic positions in Podismini and other tribes were also made in terms of reconstructed phylogeny.
\end{abstract}

\section{Key words}

grasshoppers, polymorphism, mitochondrial DNA

\section{Introduction}

The tribe Podismini Jacobson, 1905 is one of the five tribes belonging to the acridid subfamily Melanoplinae Scudder, 1897 (Cigliano et al. 2017). Podismini genera are distributed in the Palearctic and Nearctic region (Vickery 1987). They usually occur in grassland and scrub formations. Although morphology is rather variable between species, most species are clearly definable (Ito 2015). According to morphological features, Podismini is currently divided into three subtribes: Miramellina (Rehn \& Randell, 1963), Podismina (Jacobson, 1905), and Tonkinacridina (Ito, 2015). The genus group Bradynotae (Rehn \& Randell, 1963) and another 21 genera have also been considered as members of this tribe, but they have not yet been included in the subtribes (Cigliano et al. 2017).
Because of the substantial variability in morphology and even in karyotype, the taxonomy of Podismini has been excessively confused. Based on the reexamination of characters, Japanese Podismini consists of 22 species in nine genera (Ito 2015), while the phylogenetic relationship between species in the tribe is still ambiguous. The first molecular study of Podismini examined one mitochondrial gene (COII) and three ribosomal nuclear and mitochondrial genes (ITS1, 12S, and 16S) for 25 species of Podismini (Chintauan-Marquier et al. 2014). In this study, nine Japanese species of seven genera [Parapodisma dairisama (Scudder, 1897), P. mikado (Bolivar, 1890), P. subastris Huang, 1983; Sinopodisma punctata Mistshenko, 1954; Ognevia longipennis (Shiraki, 1910); Podisma kanoi (Storozhenko, 1994); Zubovskya koeppeni parvula (Ikonnikov, 1911); Fruhstorferiola okinawaensis (Shiraki, 1930); Tonkinacris sp. (Carl, 1916)] were also examined. Four of seven genera (Parapodisma Mistshenko, 1947, Sinopodisma Chang, 1940, Tonkinacris Carl, 1916, Fruhstorferiola Willemse, 1921) constituted a clade with moderate statistical support, two of seven (Podisma Berthold, 1827, Ognevia Ikonnikov, 1911) composed another clade, and Zubovskya Dovnar-Zapolsky, 1932 did not comprise a clade with any other genera.

The Japanese archipelago is composed of a multitude of smaller islands in addition to the four main islands (Hokkaido, Honshu, Kyushu, and Shikoku). The isolation of the Japanese archipelago from the Eurasian continent presumably began in Miocene (ca. 23 Myr ago), and the present form of the archipelago was reached in the approximate end of Pleistocene (Iijima and Tada 1990, Tada 1994, Yonekura et al. 2001). Interestingly, land bridges between the continent and some of the islands were formed at least three times during geochronologic periods between the Pliocene and Pleistocene as a result of changes in sea level during ice ages (Dobson and Kawamura 1998), which may have permitted backand-force movement of animals via the bridges. These complex geological events have probably shaped the present fauna and flora in Japan. The present Japanese Podismini had also presumably been derived in part from continental species group which evolved uniquely at a new place. 


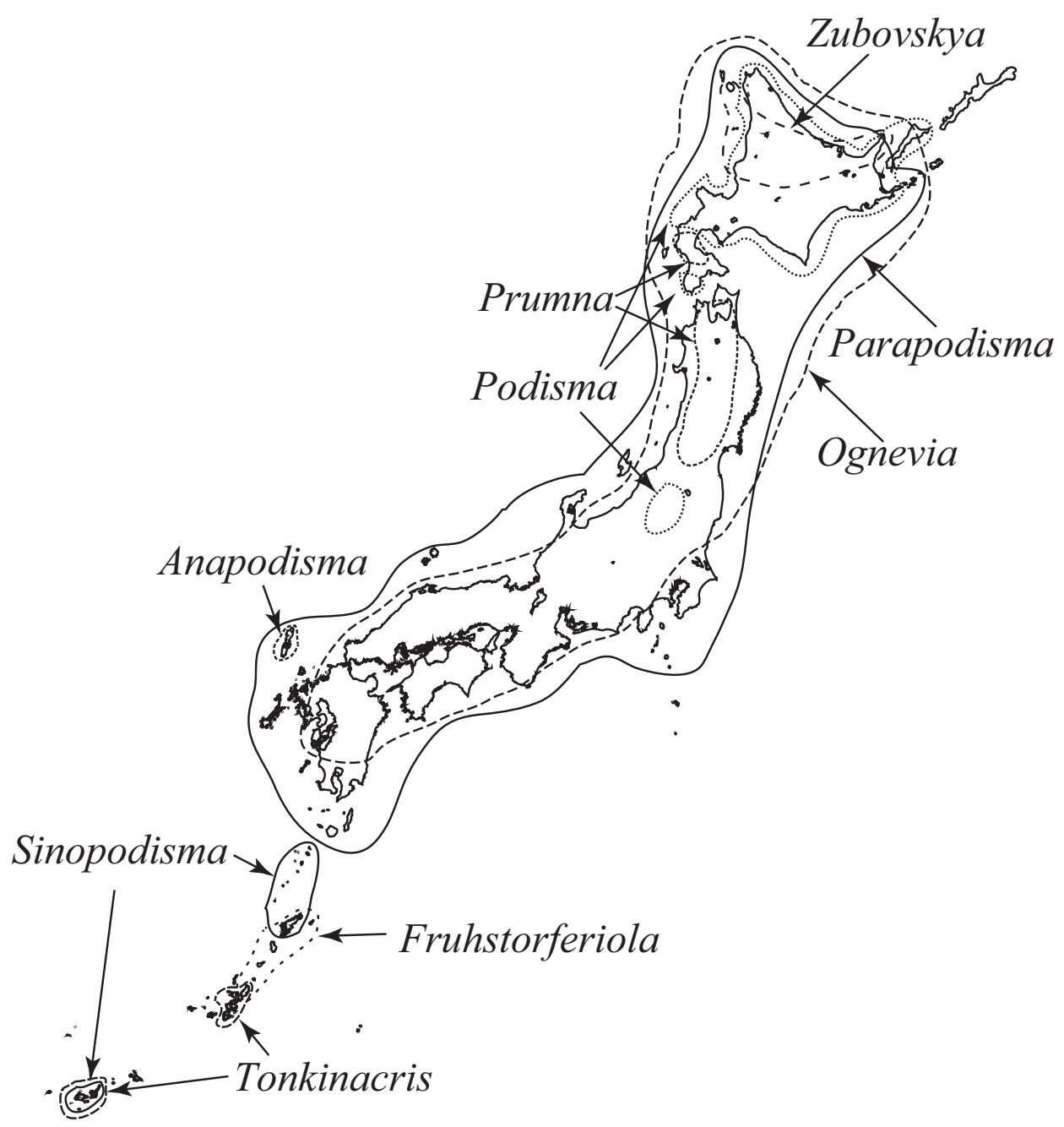

Figure 1. A map of Japan with the distribution of nine genera of Japanese Podismini.

The Japanese archipelago in broad sense consists of Hokkaido, Honshu, Shikoku, Kyushu, south Kuril Islands, and chain of islands extending from southwestern Kyushu to northern Taiwan (i.e. "Nansei Islands"). The brief distribution of nine genera in Podismini is shown in Fig. 1. Three of nine genera, Fruhstorferiola, Sinopodisma, and Tonkinacris are distributed only in Nansei Islands, presumably derived directly from continental species of the same genera. The genus Anapodisma Dovnar-Zapolskii, 1933 is found only in Tsushima Island, the southern vicinities of Korean Peninsula. The distribution of Prumna Motschulsky, 1859, Zubovskya, and Podisma is localized in a northern part of Japan (central - northern Honshu, Hokkaido and Kunashir Island) and the habitat tends to be highly fragmented especially in mountain districts. Ognevia shows the broadest distribution range among Japanese Podismini and is distributed in high altitude areas. Although other genera are apterous or have reduced forewings, flight organs are fully developed in this genus. The genus Parapodisma comprises 11 species (50\% of the Japanese podismine species) including two subspecies in Japan, and shows a variety of morphology such as body colors, genitalic characters and forewings, which has sometimes confounded their taxonomic status (Ito 2015). Although Vickery (1977) suggested that Sinopodisma, Fruhstorferiola and Parapodisma comprise Miramellina together with Zubovskya and Miramella Dovnar-Zapolskii, 1933,
Ito (2015) proposed that the first three genera with Tonkinacris should be settled in a new subtribe, Tonkinacridina based on the cladistic assessment of 23 morphological traits.

The principal aim of the present study is to examine whether Ito's (2015) hypothesis still holds if the relationship is assessed using mitochondrial DNA sequences. We utilized a partial sequence of the cytochrome c oxidase subunit I (COI) mitochondrial gene for this purpose because the sequence is used as standard in DNA barcoding and thus is feasible for comparing species other than Japanese Podismini. In order to test the hypothesis of a close affinity between all Japanese taxa, other Melanoplinae species from Eurasia and America were also drawn from GenBank and included in the analysis.

\section{Materials and methods}

Taxa studied. - A total of 82 species and subspecies were included in the analysis. All genetic sequences were acquired from GenBank except Podismini species in Japan (Table 1). The in-group consisted of 20 Podismini species and subspecies from Japan (new data) and 21 species from Eurasia and America. We included members of four other tribes of Melanoplinae: Melanoplini (19 species), Dactylotini (3 species), Dichroplini (13 species), and Jivarini (2 species). As an outgroup, we included four species of subfam- 
Table 1. Taxonomic information and GenBank accession numbers for taxa included in this study.

\begin{tabular}{|c|c|c|c|}
\hline Taxa & Sampling locality and year & $\begin{array}{l}\text { Accession } \\
\text { No. }\end{array}$ & Reference \\
\hline \multicolumn{4}{|l|}{ outgroup } \\
\hline \multicolumn{4}{|l|}{ Subfamily: Catantopinae } \\
\hline Xenocatantops humilis (Serville, 1838) & China & EU366111 & $\begin{array}{l}\text { Wang and Jiang } \\
\text { (unpublished) }\end{array}$ \\
\hline Catantops erubescens (Walker, 1870) & Pakistan & KJ672128 & Nazir et al. (unpublished) \\
\hline Diabolocatantops innotabilis (Walker, 1870) & Pakistan & KJ672135 & Nazir et al. (unpublished) \\
\hline Goniaea vocans (Fabricius, 1775) & Australia & JX033911 & Chapco 2013 \\
\hline \multicolumn{4}{|l|}{ Subfamily: Melanoplinae } \\
\hline \multicolumn{4}{|l|}{ Tribe: Dactylotini } \\
\hline Dactylotum bicolor bicolor Charpentier, 1845 & North America & KJ531421 & Woller et al. 2014 \\
\hline $\begin{array}{l}\text { Liladownsia fraile Fontana, Mariño-Pérez, Woller \& } \\
\text { Song, } 2014\end{array}$ & North America & KJ531423 & Woller et al. 2014 \\
\hline Perixerus squamipennis Gerstaecker, 1873 & North America & KJ531427 & Woller et al. 2014 \\
\hline \multicolumn{4}{|l|}{ Tribe: Dichroplini } \\
\hline Atrachelacris unicolor Giglio-Tos, 1894 & South America & FJ829334 & Dinghi et al. 2009 \\
\hline Atrachelacris gramineus Bruner, 1911 & South America & AY014360 & Amédégnato et al. 2003 \\
\hline Baeacris pseudopunctulata (Ronderos, 1964) & South America, Argentina & DQ083452 & Colombo et al. 2005 \\
\hline Chlorus bolivianus Brunner, 1913 & South America & FJ829333 & Dinghi et al. 2009 \\
\hline Dichromatos lilloanus (Liebermann, 1948) & South America & FJ829336 & Dinghi et al. 2009 \\
\hline Dichroplus obscurus Bruner, 1900 & South America & DQ084357 & Dinghi et al. 2009 \\
\hline Dichroplus pratensis Brunner, 1900 & South America, Argentina & DQ083459 & Colombo et al. 2005 \\
\hline Leiotettix pulcher Rehn, 1913 & South America, Argentina & DQ083464 & Colombo et al. 2005 \\
\hline Neopedies noroestensis Ronderos, 1991 & South America & AF539852 & Amédégnato et al. 2003 \\
\hline Pseudoscopas nigrigena (Rehn, 1913) & South America & FJ829342 & Dinghi et al. 2009 \\
\hline Ronderosia bergii (Stål, 1878) & South America, Argentina & DQ083467 & Colombo et al. 2005 \\
\hline Ronderosia forcipata (Rehn, 1918) & South America, Argentina & DQ083468 & Colombo et al. 2005 \\
\hline Scotussa daguerrei Liebermann, 1947 & South America, Argentina & DQ083469 & Colombo et al. 2005 \\
\hline \multicolumn{4}{|l|}{ Tribe: Jivarini } \\
\hline Jivarus americanus Giglio-Tos, 1898 & South America & DQ389233 & Chapco 2006 \\
\hline Jivarus gurneyi Ronderos, 1979 & South America & DQ389231 & Chapco 2006 \\
\hline \multicolumn{4}{|l|}{ Tribe: Melanoplini } \\
\hline Hypochlora alba (Dodge, 1876) & North America, USA & AF260548 & Chapco et al. 2001 \\
\hline Melanoplus bivittatus (Say, 1825) & North America, Canada & KR141481 & Hebert et al. 2016 \\
\hline Melanoplus borealis (Fieber, 1853) & North America, Canada & KR142429 & Hebert et al. 2016 \\
\hline Melanoplus bowditchi Scudder, 1878 & North America, Canada & KM535226 & Dewaard et al. (unpublished) \\
\hline Melanoplus bruneri Scudder, 1897 & North America, Canada & KM535553 & Dewaard et al. (unpublished) \\
\hline Melanoplus cinereus Scudder, 1878 & North America, Canada & KR141925 & Hebert et al. 2016 \\
\hline Melanoplus dawsoni (Scudder, 1875) & North America, Canada & KM537453 & Dewaard et al. (unpublished) \\
\hline Melanoplus deceptus Morse, 1904 & North America, Canada & KR140464 & Hebert et al. 2016 \\
\hline Melanoplus differentialis (Thomas, 1865) & North America & KJ531425 & Woller et al. 2014 \\
\hline Melanoplus femurrubrum (De Geer, 1773) & North America, Canada & KM536630 & Dewaard et al. (unpublished) \\
\hline Melanoplus gladstoni Scudder, 1897 & North America, Canada & KR140625 & Hebert et al. 2016 \\
\hline Melanoplus infantilis Scudder, 1878 & North America, Canada & KM537809 & Dewaard et al. (unpublished) \\
\hline Melanoplus mexicanus (Saussure, 1861) & North America & KJ531426 & Woller et al. 2014 \\
\hline Melanoplus montanus (Thomas, 1873) & North America, Canada & KM536558 & Dewaard et al. (unpublished) \\
\hline Melanoplus oregonensis (Thomas, 1875) & North America, Canada & KR140837 & Hebert et al. 2016 \\
\hline Melanoplus packardii Scudder, 1878 & North America, Canada & KM537414 & Dewaard et al. (unpublished) \\
\hline Melanoplus punctulatus (Uhler, 1862) & North America, Canada & KR140511 & Hebert et al. 2016 \\
\hline Melanoplus sanguinipes (Fabricius, 1798) & North America, Canada & KR143225 & Hebert et al. 2016 \\
\hline Phoetaliotes nebrascensis (Thomas, 1872) & North America, Canada & KM535800 & Dewaard et al. (unpublished) \\
\hline
\end{tabular}




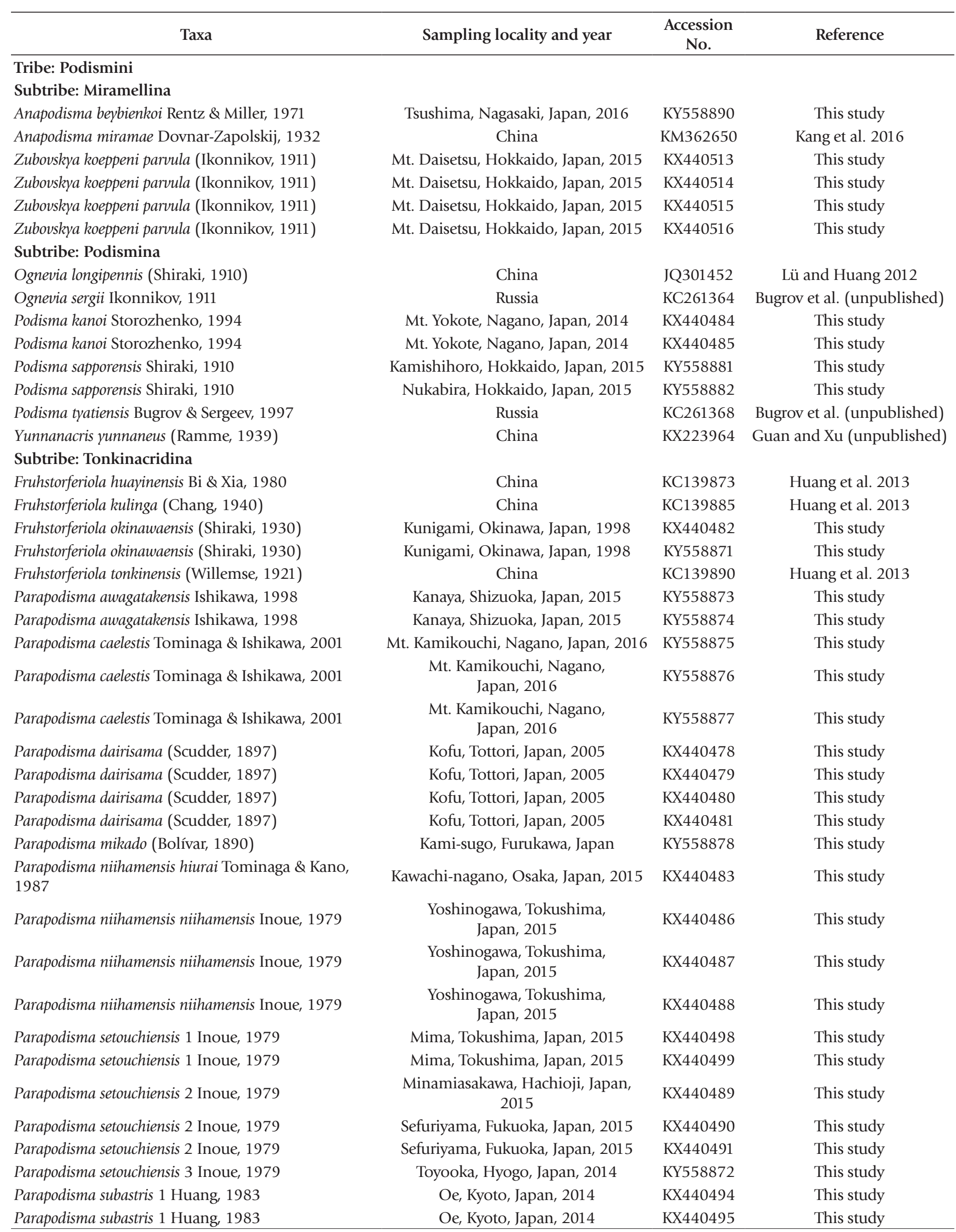




\begin{tabular}{|c|c|c|c|}
\hline Taxa & Sampling locality and year & $\begin{array}{c}\text { Accession } \\
\text { No. }\end{array}$ & Reference \\
\hline Parapodisma subastris 2 Huang, 1983 & Oe, Kyoto, Japan, 2014 & KX440496 & This study \\
\hline Parapodisma subastris 2 Huang, 1983 & Oe, Kyoto, Japan, 2014 & KX440497 & This study \\
\hline Parapodisma subastris 2 Huang, 1983 & Oe, Kyoto, Japan, 2014 & KX440492 & This study \\
\hline Parapodisma subastris 2 Huang, 1983 & Oe, Kyoto, Japan, 2014 & KX440493 & This study \\
\hline Parapodisma tenryuensis 1 Kobayashi, 1983 & Oyama, Shizuoka, Japan, 2015 & KY558883 & This study \\
\hline Parapodisma tenryuensis 1 Kobayashi, 1983 & Oyama, Shizuoka, Japan, 2015 & KY558884 & This study \\
\hline Parapodisma tenryuensis 2 Kobayashi, 1983 & Mt. Chausu, Shizuoka, Japan, 2016 & KY558885 & This study \\
\hline Parapodisma tenryuensis 2 Kobayashi, 1983 & Mt. Chausu, Shizuoka, Japan, 2016 & KY558886 & This study \\
\hline Parapodisma tenryuensis 2 Kobayashi, 1983 & Mt. Chausu, Shizuoka, Japan, 2016 & KY558887 & This study \\
\hline Parapodisma yasumatsui Yamasaki, 1980 & Sefuriyama, Fukuoka, Japan, 2015 & KX440500 & This study \\
\hline Parapodisma yasumatsui Yamasaki, 1980 & Mitsuse, Saga, Japan, 2015 & KX440501 & This study \\
\hline Sinopodisma aurata Ito, 1999 & $\begin{array}{l}\text { Kohama Island, Okinawa, } \\
\text { Japan, } 2016\end{array}$ & KY558888 & This study \\
\hline Sinopodisma aurata Ito, 1999 & $\begin{array}{l}\text { Kohama Island, Okinawa, } \\
\text { Japan, } 2016\end{array}$ & KY558889 & This study \\
\hline Sinopodisma houshana Huang, 1982 & China & KC139919 & Huang et al. 2013 \\
\hline Sinopodisma kodamae (Shiraki, 1910) & Kukuan, Taiwan, 1998 & KX440502 & This study \\
\hline Sinopodisma kodamae (Shiraki, 1910) & Kukuan, Taiwan, 1998 & KX440503 & This study \\
\hline Sinopodisma lofaoshana (Tinkham, 1936) & China & KC139936 & Huang et al. 2013 \\
\hline Sinopodisma lushiensis Zhang, 1994 & China & KC139925 & Huang et al. 2013 \\
\hline Sinopodisma punctata Mistshenko, 1954 & Tatsugo, Kagoshima, Japan, 1997 & KX440504 & This study \\
\hline Sinopodisma punctata Mistshenko, 1954 & Tatsugo, Kagoshima, Japan, 1997 & KX440505 & This study \\
\hline Sinopodisma punctata Mistshenko, 1954 & Tatsugo, Kagoshima, Japan, 1997 & KX440506 & This study \\
\hline Sinopodisma punctata Mistshenko, 1954 & Tatsugo, Kagoshima, Japan, 1997 & KX440507 & This study \\
\hline Sinopodisma punctata Mistshenko, 1954 & Tatsugo, Kagoshima, Japan, 1997 & KX440508 & This study \\
\hline Sinopodisma punctata Mistshenko, 1954 & Tatsugo, Kagoshima, Japan, 1997 & KX440509 & This study \\
\hline Sinopodisma rostellocerna You, 1980 & China & KC139947 & Huang et al. 2013 \\
\hline Sinopodisma tsinlingensis Zheng, 1974 & China & KC139903 & Huang et al. 2013 \\
\hline Sinopodisma wulingshanensis Bi, Huang \& Liu, 1992 & China & KC139909 & Huang et al. 2013 \\
\hline Tonkinacris ruficerus Ito, 1999 & Kunigami, Okinawa, Japan, 1998 & KX440510 & This study \\
\hline Tonkinacris ruficerus Ito, 1999 & Kunigami, Okinawa, Japan, 1998 & KX440511 & This study \\
\hline Tonkinacris yaeyamaensis Ito, 1999 & Mt. Omoto, Okinawa, Japan, 1998 & KX440512 & This study \\
\hline \multicolumn{4}{|l|}{ genus group Bradynotae } \\
\hline Asemoplus montanus (Bruner, 1885) & North America, Canada & KM535587 & Dewaard et al. (unpublished) \\
\hline Bradynotes obesa (Thomas, 1872) & North America & KJ531419 & Woller et al. 2014 \\
\hline \multicolumn{4}{|c|}{ Other members of Podismini - do not assign into any subtribe } \\
\hline Prumna arctica (Zhang \& Jin, 1985) & China & KC139971 & Huang et al. 2013 \\
\hline Prumna fauriei (Bolívar, 1890) & Mt. Gassan, Yamagata, Japan, 2014 & KY558879 & This study \\
\hline Prumna fauriei (Bolívar, 1890) & Mt. Gassan, Yamagata, Japan, 2014 & KY558880 & This study \\
\hline Prumna mandshurica Ramme, 1939 & China & FJ531676 & Zhao et al. (unpublished) \\
\hline Prumna primnoa (Motschulsky, 1846) & Russia & KX272717 & Sukhikh et al. (unpublished) \\
\hline Qinlingacris choui Li, Wu \& Feng, 1991 & China & FJ531684 & Zhao et al. (unpublished) \\
\hline
\end{tabular}

ily Catantopinae [Xenocatantops humilis (Serville, 1838), Catantops erubescens (Walker, 1870), Diabolocatantops innotabilis (Walker, 1870), and Goniaea vocans (Fabricius, 1775)]. We did not include Japanese species of the genus Ognevia; instead, an existing sequence for $O$. longipennis from China was examined in this paper (Lü and Huang 2012).

DNA extraction, amplification, and sequencing.- Total genomic DNA was extracted with the DNeasy Tissue Kit(QIAGEN, Hilden, Germany).
Partial gene sequences were amplified by PCR using the following primers: forward UEA7 (TACAGTTGGAATAGACGTTGATAC) and reverse UEA10 (TCCAATGCACTAATCTGCCATATTA) (Lunt et al. 1996). PCR was conducted in a $20 \mu \mathrm{l}$ volume containing $1 \mu \mathrm{l}$ of DNA, $2 \mu \mathrm{l} 10 \times$ Ex Taq Buffer $\left(\mathrm{Mg}^{2+}\right.$ free; Takara Bio Inc., Shiga, Japan $)$ with $10 \mu \mathrm{M}$ each primer, $10 \mathrm{mM}$ dNTPs, $25 \mathrm{mM} \mathrm{MgCl}_{2}$, and $5 \mathrm{U} / \mu \mathrm{l}$ of Ex Taq polymerase (Takara Bio Inc., Shiga, Japan). The mitochondrial COI fragment was amplified under the following temperature profile: initial activation at $94{ }^{\circ} \mathrm{C}$ for $3 \mathrm{~min}, 30$ cycles of denaturation at 
$94{ }^{\circ} \mathrm{C}$ for $1 \mathrm{~min}$, annealing at $45^{\circ} \mathrm{C}$ for $1 \mathrm{~min}$, and elongation at $72{ }^{\circ} \mathrm{C}$ for $2 \mathrm{~min}$, and a final elongation step at $72{ }^{\circ} \mathrm{C}$ for $7 \mathrm{~min}$. PCR products were purified by using the NucleoSpin Extract II kit (Macherey-Nagel, Düren, Germany). Samples were sequenced in both directions by using the same primers as those used for PCR and the chain termination reaction method (Sanger et al. 1977). The sequencing was carried out in a total volume of $10 \mu \mathrm{l}$ by using the Genome Lab Dye Terminator Cycle Sequencing with Quick Start Kit (Beckman Coulter, Brea, California, USA), with a cycle-sequencing profile of 40 cycles of $96{ }^{\circ} \mathrm{C}$ for $20 \mathrm{~s}, 50{ }^{\circ} \mathrm{C}$ for $20 \mathrm{~s}$, and $60{ }^{\circ} \mathrm{C}$ for $3 \mathrm{~min}$. Sequencing was performed using GenomeLab GeXP ${ }^{\mathrm{TM}}$ (Beckman Coulter, Brea, California, USA) at the Laboratory of Entomology in the Faculty of Agriculture, University of the Ryukyus, Japan. Sequences were deposited in GenBank under the accession numbers provided in Table 1.

Sequence alignment and phylogenetic analyses.- DNA sequences were aligned by using MUSCLE (Edgar 2004) with default parameters. In order to identify numts (Bensasson et al. 2001, Song et al. 2008), mitochondrial COI sequences were translated into amino acid sequences with MEGA 6 (Tamura et al. 2013) using the standard invertebrate mitochondrial genetic code. The substitution model of evolution was estimated by using the program jModelTest (Guindon and Gascuel 2003, Darriba et al. 2013). The Akaike information criterion was preferred over the hierarchical likelihood ratio test to compare the various models as recommended by Posada and Buckley (2004). The data matrices were subjected to Bayesian analysis (BI) with MrBayes v3.1. (Huelsenbeck and Ronquist 2001, Huelsenbeck et al. 2001). Bayesian analyses were performed with 10000000 generations, with a sampling of trees every 100 generations. Likelihood values were observed with Tracer v.1.4 (Rambaut and Drummond 2007); all the trees created before stability in likelihood values were discarded as a 'burn-in' (first 1200 trees). Maximum likelihood (ML) analysis was implemented in Phyml (Guindon and Gascuel 2003). For the bootstrapping analyses 1000 pseudoreplicates were generated. FigTree 1.4.0 (Rambaut and Drummond 2012) was used to visualize the trees.

\section{Results}

The total alignment of the COI gene consisted of 646 bp including 53\% variable sites and 48\% parsimony-informative sites. The analysis of the partial mitochondrial COI gene amplified from 59 individuals revealed 20 different haplotypes. Among them individuals were identical for 14 species except Parapodisma subastris, $P$. setouchiensis, and P. tenryuensis. The model F81 + G (gamma distribution shape parameter $G=0.6220$ ) was determined to be the most justified.

The Bayesian inference and maximum likelihood analyses resulted in similar trees, the only differences between them being the degree of statistical support for the recovered nodes (Fig. 2). Nodal supports were generally poor across all backbone nodes. ML bootstrap percentages were lower than BI posterior probabilities. The relationship between Podismini and the related tribes were not fully resolved and varied depending on the nodes.

Melanoplinae were divided into six distinctive lineages and appeared as a polytomy of four clades (II - VI). Dactylotini (I) was placed as sister to the other five lineages. The second and third lineages (II and III) consisted of two genera (seven species) and one genus (three species) of Podismini, respectively. The fourth clade (IV) clustered the genera of Dichroplini. Within clade five (V),
Melanoplini formed a monophyletic group with strong support [posterior probability $(\mathrm{PP})=1.00$, bootstrap value $(\mathrm{BV})=77$ ]. The sixth clade (VI) was constituted of the rest of the members of Podismini and Jivarini.

Thirteen genera of Podismini included in this study formed three separate clades. The Japanese Podismini, except Anapodisma beybienkoi Rentz \& Miller, 1971, were placed in a well supported subclade with high nodal support $(\mathrm{PP}=1.00, \mathrm{BV}=100)$ within clade VI. Nine species of Sinopodisma and four species of Fruhstorferiola included in the analysis nested in different clades. The majority of Podismini species formed clade VI together with Jivarini species. The basal relationships within clade VI were not resolved. Clade VI consisted of 13 branches with a single terminal taxon: nine species of Parapodisma, Bradynotes obesa (Thomas, 1827), Podisma tyatiensis Bugrov \& Sergeev, 1997, Qinlingacris choui Li \& Feng, 1991 and Asemoplus montanus (Bruner, 1885), and five subclades including members of three podismine subtribes. Tonkinacridina comprising Parapodisma, Tonkinacris, Fruhstorferiola and Sinopodisma did not constitute a single clade. Among 11 species of Parapodisma, P. tenryuensis Kobayashi, 1983 (two haplotypes), P. caelestis Tominaga \& Ishikawa, 2001, P. mikado, and P. awagatakensis Ishikawa, 1998 were clustered together with moderate statistical support (Fig. 2).

\section{Discussion}

The present study obtained some interesting results with respect to the relationships within Japanese Podismini. The subclade of Japanese Podismini within clade VI (indicated with light green frames in Fig. 2) included genera which have been attributed to three podismine subtribes, but Tonkinacridina did not form a single clade. Two different methodological inferences on phylogeny (BI, ML) yielded mostly congruent nodes, but the trees were poorly resolved (Fig. 2). Most taxa were determined within a large polytomy of Podismini, in which only a few clades have been recovered. Support remained generally low for the deeper nodes, as was expected for a phylogeny constructed using COI only, but some more derived nodes had higher values (Fig. 2).

Our results are compared with tree inferred by ChintauanMarquier et al. (2014) who were the first to show molecular phylogeny of Eurasian Podismini including nine Japanese species. The most important finding is that Podismini did not constitute monophyly as previously suggested in Chintauan-Marquier et al. (2014), but there are some incongruent patterns between the two. In the present results, most of the species of Japanese Podismini, except Anapodisma, constituted a single clade (Fig. 2), whereas species belonging to Podismina and Miramellina constituted separate clades from Tonkinacridina in the previous molecular study (Chintauan-Marquier et al. 2014). Although the statistical support was not very strong, a monophyly of Tonkinacridina was supported in the previous study, a view concordant with morphological inspection (Ito 2015). On the contrary, our data placed the continental species of Tonkinacridina in different clades (clade II and III in Fig. 2) from Japanese Tonkinacridina. Of course, strict comparisons between these studies are impossible at this stage since continental Tonkinacridina was not included in the previous dataset (Chintauan-Marquier et al. 2014). The view of monophyly in Tonkinacridina is quite doubtful. We can postulate that the observed continental and Japanese species of Tonkinacridina assigned in different clusters reflect somewhat historical migration events coupled with geological processes described above and subsequent convergent/parallel evolution has eventually accumulated 


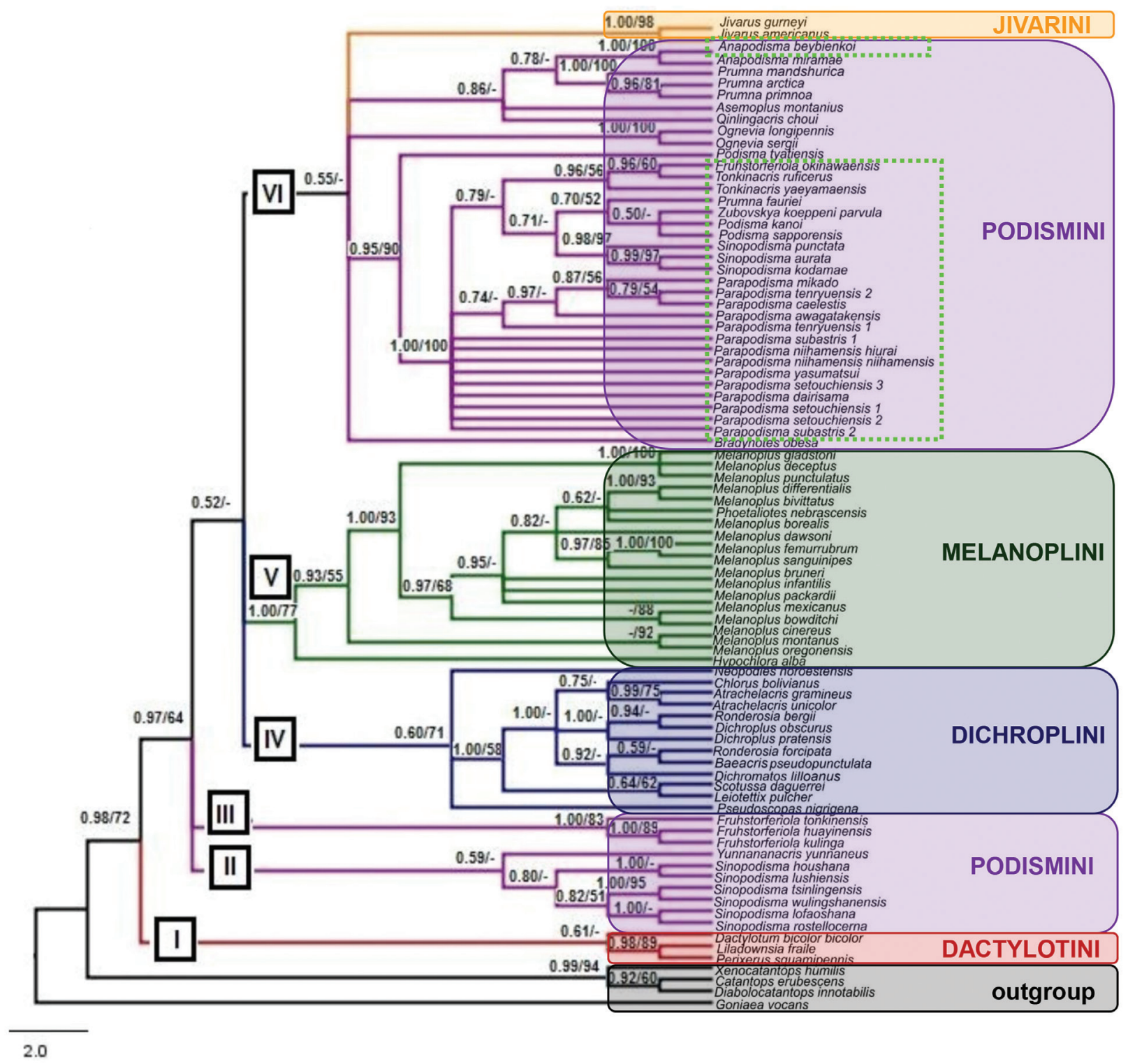

Figure 2. Phylogenetic tree of Podismini based on the Bayesian analysis (BI) of concatenated COI sequences. BI posterior probability (PP) and maximum likelihood bootstrap values (BV) are shown near resolved branches (only support values above 50\% are shown) as $\mathrm{PP} / \mathrm{BV}$. The respective clades are marked with a square and Roman numeral. We examined Ognevia longipennis from China because of the availability and thus did not treat this specimen as Japanese Podismini (see also text). Light green frames denote the Japanese Podismini analyzed in the present study.

in morphology. This conjecture could be evaluated by estimating coalescent time of clades using a mitochondrial clock.

In the genera compared, Parapodisma is particularly interesting because this includes a vast variety of morphological variation in genital and external characters (Kawakami 1999, Kawakami and Tatsuta 2010), while almost no variation in karyotype exists in contrast to morphology (Inoue 1985). Even in the same species, various forms in forewings and body colors are often found and thus have caused synonymous species/subspecies (Kawakami 1999). This taxonomic disorder still continues in this group partly because there is no robust phylogenetic tree that enables to disentangle "genuine" relationships from homoplasy in morphology. Unfortunately, most species constituted polytomy because of a lack of statistical power, a subclade comprised of closely related species, Parapodisma mikado, P. tenryuensis,
P. caelestis, and P. awagatakensis was detected (Fig. 2). While $P$. mikado shows an extended distribution from vicinities of northern Japan and Russia such as Sakhalin, Kunashir, and Hokkaido to the middle of Honshu, the other three species are distributed in narrower regions in Honshu. In particular, populations of $P$. caelestis are limited to narrow habitats such as flower fields with a variety of wild grass and alpine flora on the top of mountains and $P$. awagatakensis inhabits patchy forest edges with very low population density; thus are considered to be vulnerable to unexpected environmental degradation. According to the cladistic assessment in morphology, $P$. awagatakensis was clustered together with $P$. mikado and $P$. dairisama, whereas $P$. tenryuensis constituted holophyly with $P$. caelestis and $P$. takeii (Takei, 1914) (this species is not included in our study) (Ito 2015), a result dissimilar to the present molecular relationship. Rigorous character sampling 
with additional molecular data is definitely required for resolving the complex relationship between morphological and genetic similarity. We also have to pay attention to possible hybridization between partly sympatric species, while no clear evidence for this has been obtained even in closely related species (Kawakami and Tatsuta 2010).

The genus Sinopodisma emerged as a highly paraphyletic group in which species did not appear closely related and nested in different clades. Likewise, although Sinopodisma punctata resembles S. kodamae (Shiraki, 1910) in several morphological features such as body color and genital appendages in comparison with $S$. aurata Ito, 1999, the inferred tree supports the closer relationship between $S$. aurata and S. kodamae. Furthermore, most of the continental species of Sinopodisma are distinguished from $S$. punctata and $S$. aurata in respect of the features in pronotum and cerci (Ito 2015). We postulate that the morphological similarities within Sinopodisma are the result of convergent evolution; further intensive studies based on molecular data are definitely necessary for the reliable underpinning of phylogenetic relationships.

The present investigation generated additional evidence for the relationships within Melanoplinae. In present trees, Dichroplini species were recovered as a monophyletic group, in agreement with the analysis of Chapco (2006) and Woller et al. (2014). On the other hand, Chintauan-Marquier et al. (2011) found the paraphyly of Dichroplini. In our analysis, Dactylotini and Melanoplini species each formed a monophyletic clade. Previous studies of Dactylotini including Hesperotettix viridis Thomas, 1872 discovered that this tribe is paraphyletic (Chapco 2006, Chintauan-Marquier et al. 2011, Woller et al. 2014). The prior analysis of the melanopline tribes placed Jivarini in a basal position in the subfamily (Amédégnato et al. 2003, Woller et al. 2014). In our results, Jivarini species were clustered together with Podismini representatives. Different studies (Litzenberger and Chapco 2001, Chintauan-Marquier et al. 2014, Woller et al. 2014) recovered Podismini as a monophyletic group, while Litzenberger and Chapco (2003) hypothesized a paraphyly of Podismini.

Although a single mitochondrial gene may lead to a half answer for the whole picture of relationships of higher taxa, the present study provides some significant implications of phylogenetic position. One of the great merits of this study is that the gene has extensively been used for DNA barcoding studies in insects, including grasshoppers, which enables us to examine a store of sequences in a global database (Cameron 2014). The selected mitochondrial COI gene allowed us to estimate intra- and interspecies relationships because of the presence of both variable and conserved regions as well as a heterogeneous evolutionary rate across the gene (Lunt et al. 1996). Simultaneously, we also should keep in mind that the shorter COI gene sequences may include paralogous nuclear mitochondrial pseudogenes (numts) that are apt to induce incorrect inference for phylogenetic relationships (Song et al. 2008, 2014). We need further investigations with orthologous genes for elucidating the distinct phylogenetic position of taxa of interest.

\section{Acknowledgments}

We are greatly indebted to Yasushi Kawakami, Keiichiro Shikata, Yoshikazu C. Sugano, Shin-ichi Akimoto, Koji Mizota, Masakazu Sano, Yasushi Sato, Takeshi Sasaki, Chiharu Koshio, and Shinichi Kudo for their help in collecting materials. Thanks are also due to Gen Ito for enthusiastic discussions and providing valuable materials and documents. Collecting materials at special protection zone in Daisetsuzan National Park and in Southern Alps Na- tional Park were approved by the Ministry of Environment of Japan (Nos. 1508181, 1605174, 1605023, 1607014). This work has been supported in part by JSPS KAKENHI Grant Numbers 15F15762, 25291088, and 25304014 to Haruki Tatsuta and Beata Grzywacz.

\section{References}

Amédégnato C, Chapco W, Litzenberger G (2003) Out of South America? Additional evidence for a southern origin of melanoplinae grasshoppers. Molecular Phylogenetics and Evolution 29: 115-119. https:// doi.org/10.1016/S1055-7903(03)00074-5

Bensasson D, Zhang D-X, Hartl DL, Hewitt GM (2001) Mitochondrial pseudogenes: evolution's misplaced witnesses. Trends in Ecology and Evolution 16: 314-321. https://doi.org/10.1016/S0169-5347(01)02151-6

Cameron SL (2014) Insect mitochondrial genomics: implications for evolution and phylogeny. Annual Review of Entomology 59: 95-117. https://doi.org/10.1146/annurev-ento-011613-162007

Chapco W (2006) A note on the phylogenetic position of Duartettix montanus within the subfamily Melanoplinae. Journal of Orthoptera Research 15: 59-63. https://doi.org/10.1665/10826467(2006)15[59:ANOTPP]2.0.CO;2

Chapco W (2013) A note on the molecular phylogeny of a small sample of Catantopine grasshoppers. Journal of Orthoptera Research 22: 15-20. https://doi.org/10.1665/034.022.0103

Chapco W, Litzenberger G, Kuperus WR (2001) A molecular biogeographic analysis of the relationships between North American melanopline grasshoppers and their Eurasian and South American relatives. Molecular Phylogenetics and Evolution 18: 460-466. https://doi. org/10.1006/mpev.2000.0902

Chintauan-Marquier IC, Jordan S, Berthier P, Amédégnato C, Pompanon F (2011) Evolutionary history and taxonomy of a short-horned grasshopper subfamily: The Melanoplinae (Orthoptera: Acrididae). Molecular Phylogenetics and Evolution 58: 22-32. https://doi. org/10.1016/j.ympev.2010.07.003

Chintauan-Marquier IC, Amédégnato C, Nichols RA, Pompanon F, Grandcolas P, Desutter-Grandcolas L (2014) Inside the Melanoplinae: New molecular evidence for the evolutionary history of the Eurasian Podismini (Orthoptera: Acrididae). Molecular Phylogenetics and Evolution 71: 224-233. https://doi.org/10.1016/j.ympev.2013.09.009

Cigliano MM, Braun H, Eades DC, Otte D (2017) Orthoptera Species File. Version 5.0/5.0. http://Orthoptera.SpeciesFile.org [accessed 14.01.2017]

Colombo P, Cigliano MM, Sequeira AS, Lange CE, Vilardi JC, Confalonieri VA (2005) Phylogenetic relationships in Dichroplus Stål (Orthoptera: Acrididae: Melanoplinae) inferred from molecular and morphological data: testing karyotype diversification. Cladistics 21: 375-389. https://doi.org/10.1111/j.1096-0031.2005.00068.x

Darriba D, Taboada GL, Doallo R, Posada D (2013) jModelTest 2: more models, new heuristics and parallel computing. Nature Methods 9: 772. https://doi.org/10.1038/nmeth.2109

Dinghi PA, Confalonieri V, Cigliano MM (2009) Phylogenetic studies in the South American tribe Dichroplini (Orthoptera: Acrididae: Melanoplinae): is the Paranaense-Pampeano informal genus group a natural clade? Zootaxa 2174: 51-62.

Dobson M, Kawamura Y (1998) Origin of the Japanese land mammal fauna: Allocation of extant species to historically-based categories. Daiyonki Kenkyu (The Quaternary Research) 37: 385-395. https:// doi.org/10.4116/jaqua.37.385

Edgar RC (2004) MUSCLE: multiple sequence alignment with high accuracy and high throughput. Nucleic Acids Research 32: 1792-1797. https://doi.org/10.1093/nar/gkh340

Guindon S, Gascuel O (2003) A simple, fast and accurate algorithm to estimate large phylogenies by maximum likelihood. Systematic Biology 52: 696-704. https://doi.org/10.1080/10635150390235520

Hebert PDN, Ratnasingham S, Zakharov EV, Telfer AC, Levesque-Beaudin V, Milton MA, Pedersen S, Janetta P, deWaard JR (2016) Counting animal species with DNA barcodes: Canadian insects. Philosophical Transactions of the Royal Society B 371. https://doi.org/10.1098/rstb.2015.0333 
Huang J, Zhang A, Mao S, Huang Y (2013) DNA barcoding and species boundary delimitation of selected species of Chinese Acridoidea (Orthoptera: Caelifera). PLoS ONE 8: e82400. https://doi.org/10.1371/ journal.pone.0082400

Huelsenbeck JP, Ronquist F (2001) MrBAYES: Bayesian inference of phylogeny. Bioinformatics 17: 754-755. https://doi.org/10.1093/bioinformatics/17.8.754

Huelsenbeck JP, Ronquist F, Nielsen R, Bollback JP (2001) Bayesian inference of phylogeny and its impact on evolutionary biology. Science 294: 2310-2314. https://doi.org/10.1126/science.1065889

Iijima A, Tada R (1990) Evolution of Tertiary sedimentary basins of Japan in reference to opening of the Japan Sea. Journal of the Faculty of Science. University of Tokyo, Section 2: Geology, Mineralogy, Geography, Geophysics 22: 121-171.

Inoue M (1985) A taxonomic revision of Japanese Acridoidea (Orthoptera) with special reference to their karymorphology. Transactions Shikoku Entomological Society 17: 103-183.

Ito G (2015) A systematic study of the grasshopper tribe Podismini in Japan (Orthoptera: Acrididae). Insecta Matsumurana New Series 71: $1-119$.

Kang AR, Kim MJ, Park IA, Kim KY, Kim I (2016) Extent and divergence of heteroplasmy of the DNA barcoding region in Anapodisma miramae (Orthoptera: Acrididae). Mitochondrial DNA 27: 3405-3414.

Kawakami Y (1999) Geographic variation of the brachypterous grasshopper Parapodisma setouchiensis group in Western Honshu, with its taxonomic revision. Species Diversity 4: 43-61.

Kawakami Y, Tatsuta H (2010) Variation in the shape of genital appendages along transect of sympatric and allopatric area of two brachypterous grasshoppers, Parapodisma setouchiensis and P. subastris (Orthoptera: Podisminae). Annals of the Entomological Society of America 103: 327-331. https://doi.org/10.1603/AN09074

Litzenberger G, Chapco W (2001) Molecular phylogeny of selected Eurasian Podismine Grasshoppers (Orthoptera: Acrididae). Annals of the Entomological Society of America 94: 505-510. https://doi. org/10.1603/0013-8746(2001)094[0505:MPOSEP]2.0.CO;2

Litzenberger G, Chapco W (2003) The North American Melanoplinae (Orthoptera: Acrididae): A molecular phylogenetic study of their origins and taxonomic relationships. Annals of the Entomological Society of America 96: 491-497. https://doi.org/10.1603/00138746(2003)096[0491:TNAMOA]2.0.CO;2

Lunt DH, Zhang DX, Szymura JM, Hewitt GM (1996) The insect cytochrome oxidase I gene: evolutionary patterns and conserved primers for phylogenetic studies. Insect Molecular Biology 5: 153-165. https://doi.org/10.1111/j.1365-2583.1996.tb00049.x
Lü H-J, Huang Y (2012) Phylogenetic relationship among some groups of orthopteran based on complete sequences of the mitochondrial COI gene. Zoological Research 33: 319-328. https://doi.org/10.3724/ SP.J.1141.2012.03319

Posada D, Buckley TR (2004) Model selection and model averaging in phylogenetics: advantages of the AIC and Bayesian approaches over likelihood ratio tests. Systematic Biology 53: 793-808. https://doi. org/10.1080/10635150490522304

Rambaut A, Drummond AJ (2007) Tracer v1.4: MCMC trace analyses tool. http://beast.bio.ed.ac.uk/Tracer

Rambaut A, Drummond A (2012) FigTree: Tree Figure Drawing Tool, v1.4.2. Institute of Evolutionary Biology, University of Edinburgh.

Sanger F, Nicklen S, Coulson AR (1977) DNA sequencing with chainterminating inhibitors. Proceedings of the National Academy of Sciences of the United States of America 74: 5463-5467. https://doi. org/10.1073/pnas.74.12.5463

Song H, Buhay JE, Whiting MF, Crandall KA (2008) Many species in one: DNA barcoding overestimates the number of species when nuclear mitochondrial pseudogenes are coamplified. Proceedings of the National Academy of Sciences of the United States of America 105: 13486-13491. https://doi.org/10.1073/pnas.0803076105

Song H, Moulton MJ, Whiting MF (2014) Rampant nuclear insertion of mtDNA across diverse lineages within Orthoptera. PLoS ONE 9: e110508. https://doi.org/10.1371/journal.pone.0110508

Tada R (1994) Paleoceanographic evolution of the Japan Sea. Palaeogeography, Palaeoclimatology, Palaeoecology 108: 487-508. https://doi. org/10.1016/0031-0182(94)90248-8

Tamura K, Stecher G, Peterson D, Filipski A, Kumar S (2013) MEGA6: Molecular Evolutionary Genetics Analysis version 6.0. Molecular Biology and Evolution 30: 2725-2729. https://doi.org/10.1093/molbev/mst197

Vickery VR (1977) The value of cytology in taxonomy with particular reference to the Podismini (Acridoidea: Acrididae: Melanoplinae). Revista de la Sociedada Entomologica Argentina 36: 89-95.

Vickery VR (1987) The orthopteroid insects in northern North America: updating and rationalizing recent works. The Canadian Entomologist 19: 1043-1054. https://doi.org/10.4039/Ent1191043-11

Woller DA, Fontana P, Marińo-Pérez R, Song H (2014) Studies in Mexican Grasshoppers: Liladownsia fraile, a new genus and species of Dactylotini (Acrididae: Melanoplinae) and an updated molecular phylogeny of Melanoplinae. Zootaxa 3793: 475-495. https://doi.org/10.11646/ zootaxa.3793.4.6

Yonekura N, Kaizuka S, Nogami M, Chinzei K (2001) Introduction to Japanese geomorphology. Regional Geomorphology of the Japanese Islands, 1. University of Tokyo Press, 349 pp. [In Japanese] 